\title{
Communication strategy to improve women's political participation in Indonesia
}

\author{
Uspal Jandevi a,1,*, \\ a Nanjing Normal University, Wenyuan Road Qixia District, Nanjing 210046, P.R. China \\ 130185309@ stu.njnu.edu.cn*; \\ * corresponding author
}

ARTICLE INFO

Article history

Received 2019-09-09

Revised 2019-09-14

Accepted 2019-09-19

Keywords

Politic

Communication

Strategy

Women

Participation

\section{ABSTRACT}

This paper aims to determine how the communication strategy used to improve women's political participation in Indonesia. The essence of the communication strategy is planning and management to achieve one goal. To reach this goal, strategy functioned not only as a roadmap to lead the wav but also has to show how the operational tactics. Communication strategy is a blend of communication planning and communication management to attain a specific purpose. To compose communication strategy, there are several factors which have to be considered necessary. First, knowing the public is the first step fora communicator to create effective communication. Note that in the communication process, the audience is active instead of passive. So between the communicator and communicant not only occurs relations but also influence that affect each other. Second, compile message, namely determining theme and subject. The main requirement to change public from this message is the capability to arouse their concern. The concern is a central observation. Thus not all who observed could trigger attention. Therefore the beginning of communication effectivity is the rise of the public's attention toward the delivered messages.

This is an open-access article under the CC-BY-SA license.

\section{Introduction}

The communication strategy is mostly planning and management to achieve a single goal. To achieve that goal, the policy does not serve as a roadmap that only shows direction, but instead must demonstrate how the operational tactics are. Communication strategy is a combination of communication planning and communication management to achieve a goal [1].

In communication, to devise a communication strategy, there are several important factors to be aware of. First, getting to know audiences is the first step for communicators to create effective communication. Given in the process of communication, the audience was not at all passive, but active. So between communicators with the communities have not only mutual relations but also influence each other. Secondly, composing a message is determining the theme and material. The main requirement in controlling the audiences of the word is to raise attention. Caution is a centralized observation. Therefore not all that is observed can cause attention. Thus the beginning of effectiveness in communication is the rise of the attention of the audience to the messages delivered [2]. 
It is compliant with the Attention to Action procedure. That means raising attention (attention) to move someone or people further to do activities (Action) according to the purpose formulated. In determining the theme or content of the message that is pointed to the audience according to the condition, it can be one side issue, a presentation of a unilateral matter, only favorable terms or only negative terms. Both series issue, a problem presented both negatively and positives [3].

Then the latter is related to the selection of communication media because to achieve the target of communication we can choose one or a combination of several media, depending on the objectives to be made, the message conveyed, and the technique Used because each medium has its own his weaknesses as a tool. The communication strategy requires proper planning and preparation by observing the above factors to obtain optimal results [3].

The discussion that we will do in this study is that nearly a decade of the discourse of representation and participation of women in politics continues to rise to almost dominating the political agenda, thanks to the firm of the organization's Women and activists who care about the problem of women voicing it. One of the central issues that then emerged is the implementation of quotas of at least $30 \%$ female involvement in the elections. The discourse that evolves and gives birth to the control debate around gender and democracy issues. The dispute arises as a result of three factors that became part of the past of the Indonesian nation. The first factor is the historical (historical) factor, where the nation's history records how low the representation of Indonesian women is in its involvement when the decision-making process occurs.

The second factor has to do with continuing political reform, where the transition of democratic life has widened opportunities for women and other community sectors to express their views on formulating and Voice their demands with greater gender awareness and sensitivity in each government and legislative policy [4].

Then the factor when it comes to the economic crisis of 1997 is the rise of demands on the representation of women in each level and all aspects of political life. The financial crisis that struck has affected women's lives a lot [5]. Due to the crisis's high maternal and infant mortality, the worsening of maternal and child health, the increasing current of female migrant workers, the growing numbers of school dropouts and unemployment. The most victims in this crisis are women so encouraging them to rise, voicing their needs, and retaining their rights. These adverse impacts raise awareness about the importance of putting together a more gender-sensitive political agendas.

The factors mentioned above have created an atmosphere whereby all community organizations, NGOs, activists, politicians, and international agencies can jointly influence the discourse and direction of government policy concerning Involvement of Indonesian women in political life. Many female NGOs who are engaged in politics now begin to raise political awareness by the people of the Compton. Therefore, now the politic institutions in Indonesia have an intense pressure to make the gender issue as a central issue in the process of democratization, the presence of women in the political world is one of the ideal conditions for the realization of gender equality [4].

In short, the need to improve the political representation of women in Indonesia is based on an awareness that all the priorities and the political agenda must be revamped, and the reshuffle will be impossible if continuing to use the system Traditional. If women want to look ahead and hold various public strategic positions, then they will be able to build and establish new social and economic values that can accommodate the aspirations of women's needs. Improving women representation means also increasing women's effectiveness in influencing public and political policies taken [6].

Women's political participation is a meaningful manifestation of the involvement of women in the decision-making process in public institutions and legal entities. The primary purpose of this political participation is that women have the access and structural control over the quality and quantity of representation of women on it, without being distinguished from the male involvement in the decision making the process [2].

In subsequent developments, women's political participation was expected to influence public policy and encouraged a wide range of gender-sensitive open systems, both on legislative and executive lines due to The quality and quantity of the political representation of women in it. Therefore, women must first get a civic education to be more capable and empowered in struggling 
to become an active member of the political party, then become representatives of the party in the legislative institution through the quota provided Especially for women .

In a democratic country, elections have been regarded as one of the most appropriate mechanisms for recruitment of national leaders, in which nominated politicians introduce policies that reflect public opinion. This emphasizes the function of political recruitment, representation, governmental creation, and policy formulation of the elections, backed by political parties. Therefore, by participating through the polls, the quarterback can be involved in implementing some of the essential functions of the votes, which affects the process of formulating public policy, both in the executive and legislative environment [7].

In legislative institutions, the role of women's politics in influencing public policy is becoming increasingly active because it is essentially the institution that has supported the critical position in the government machinery. This political institution generates laws that become legal boundaries of the implementation of executive governance. This governmental institution was honored because it consisted of politics that the party-appointed to represent the people. The Institute acts as a National Council of debate, a national forum where government policies and significant emerging issues can be discussed and analyzed openly. Therefore, through this political institution women can devote most of its energy, time and mind in the process of making legislation, which gives it several structural capacities to form or influence public policy [8]. However, the political participation of women fi in elections and such legislative agencies could never be conducted without the civic education process that political parties run. Therefore, the political party's role was required to do political education through various media.

Lack of representation of women in Parliament is caused by a series of obstacles that limit their willingness and progress. Therefore, various strategies should be studied simultaneously to overcome these obstacles so that the goal to increase women's participation in legislative elections can be realized. And those obstacles are gender-sensitive.

As we have discussed above that decision-making in the Patriarchy community both in the legislature and other public issues are always dominated by men. The dominance of this decisionmaking resulted in gender inequality on aspects such as education, training, health status, access to resources, and so on. Conceptual gender sensitivity is the ability to understand gender inequality, especially in the division of work and decision making resulting in reduced chance and low women's social status compared to men. The issue of women's participation in political activities in Indonesia found momentum very important since the new order authoritarian regime in 1998, which became the symbol of the rise of democracy in the country. Along with the growing issue of civil society empowerment, freedom of opinion and assembly, freedom of the press, a multiparty system of diversity, as well as local politics and regional autonomy, the growing issue of women empowerment in politics. Throughout the years 2001, debates over the representation and participation of women's politics are increasing and dominating the political agenda, such as the persistence of civil society activists ' organizations that are vocal in voicing this issue. One of the most critical problems they sounded is the implementation of a quota of $30 \%$ representation for women in the election process.

In the post-Reformation era of the New order collapse, the direction of women's political struggle through the election process was obvious since the decade of 2000, because in Indonesia began to grow and develop rapidly around national and local decision-making. Which Marked by the participation of women as members of the MPR, DPR, DPD, and DPRD, both provincial and Regency/city.

The political struggle eventually resulted in encouraging results by the introduction of female involvement in political activities, particularly in the People's Representative Council, through the enforcement of law No. 12/2003 on general elections Members of the House of Representatives, DPD, and DPRD, where women are entitled to a minimum representation quota of $30 \%$ as a member of the DPR, provincial and Regency/City DPRD (article 65 paragraph [1]).

In response to the enforcement of a minimum $30 \%$ representation of the quota, many political parties are trying to involve women as new cadres to be nominated as candidates for legislative institutions, both at national and regional levels. But raising a female legislative candidate is not easy. One of the reasons is the lack of the cauterization of the political parties that do not go well to 
prepare women cadres to be interested in the political world. And for the parties concerned this is a dilemma because based on the regulation KPU No 17 the Year 2013 has asserted that the party must be able to meet the quota of $30 \%$ women in his candidacy. Otherwise, the form will be returned and Threatened sanctions.

\section{Theoretical Framework}

\subsection{Participation}

Participation means to contribute to the role of activities, attendance, and participation. In politics, engagement can be interpreted as citizen participation in the political process. The concept of the involvement in politics does not only mean that the colors of the country support the decisions or policies outlined by the leader, but instead refer to participation at all stages of the system, from decision-making to assessment Decisions, including opportunities to participate in the execution of decisions. About this, Huntington stated that political participation was an activity in influencing the direct order, namely by the perpetrator himself without any intermediaries, or indirectly, that is through People who can channel it to the government [9].

Furthermore, according to Almond political participation can be done through two forms, namely (1) conventional partnership, which is a form of regular and legal governmental assistance through voting, political discussions, campaign activities, formation and/ or joining interest groups; and (2) non-conventional political partition, which includes petitions, action demonstrations and strikes, confrontations, acts of political violence over property and action against man [10].

In the meantime, in order to achieve political participation, it is necessary to form political involvement, including the participation of people in many politics occurring in non-governmental decision-making institutions, such as political parties, unions, (RT) and community pillars (RW), business, school, and social-religious organizations [11].

In connection with that, Huntington and Nelson provided restrictions that political participation could be undertaken by the activities of citizens as a private citizen, aiming to influence decision making by the Government. This political participation can be individual or collective, organized or spontaneous, steady or sporadic, with peace or violence, legal or illegal, effective or ineffective. Only, for citizens to participate in politics, there needs to be engagement and the media provision of political participation. That level of involvement is usually increasingly higher when citizens realize that they are being ruled, their rights and interests do not get adequate attention from the Government, and they demand to have a vote in the government. The feeling of having to be involved in politics is usually beginning to emerge in educated, prosperous, and prominent people.

At a minimum level, they feel that they should participate in politics in order for their position as their citizens can thrive, and their rights and interests can be respected by the ruling political institutions.

\subsection{Persuasive Communication}

An activity that is always present in the world of politics is political persuasive. Persuasive is the nature of persuasion, while in the popular Scientific Dictionary of Persuasion is a convincing energy, persuasion, wreath that outlines a problem or circumstance evidenced by the data and facts aimed at persuading or invite or influence the reader, so they want to follow or do as expected the communicator, meanwhile for its own persuasive sense is convincing, soft, nonviolent [12].

Dan Nimmo mentions that persuasive is a purposeful or stakeholder communication. The main purpose of persuasive is to elicit a feeling of responsiveness to others (in the political world than the communities or communities). There are three understandings of persuasive proceedings. Firstly, persuasion usually involves a purpose, a communicator effort to achieve the goal through breeding. Second, persuasive is dialectical. And the third has a form of response. So it can be concluded that political persuasive is an invitation, persuasion, seduction, with a nonviolent form that is done by political communicators to the community as a community with the aim that the community can provide support, A response, sympathy for him in terms of power in a country [13].

In a life of reality, political persuasive is more often when we are approaching a general election, from the level of the most basic to the highest level of a nation. Based on the Cangara mention that 
in the preparation of political messages in persuasive communication, there are several techniques used, among others:

a. Fear Appeal, meaning how a political communicator devises a persuasive message containing the element of giving fear to the communities. Usually, this persuasive is done by the communities who already have power somewhere.

b. Emotional appeal, the main element of this technique is emotion. So a persuasive message of politics is assembled in such a way that it can stir or raise the emotions of communities, for example by revealing the problem of religion, ethnicity, economic gaps that are happening, discrimination of minorities and other Etc.

c. Reward appeal, a full arrangement of promises delivered by the communicators, with the promise of society will be more trusting of vision-mission delivered by the communicator.

d. The motivational appeal, this technique further emphasizes the diversity of a politician to give an internal psychological urge to the community, not on promises so that the public can follow the messages delivered.

e. The humorous appeal, this latter technique is more concerned with how a persuasive message is compiled so that it does not cause "saturation" in society. Because of humor, lightweight, delicious, refreshing will be more easily acceptable than very serious messages.

Hatfield Cengara added that the messages compiled using the above-mentioned techniques would be effective when presented with the propagandists therein. Propaganda can be said to be a form of destruction that is popular in the political world. Propaganda is derived from the word propagate, which means "to develop" or "to extract." The term means a series of messages aimed at influencing the opinions and behavior of the Community or group of people [1].

Propaganda does not convey objectively the information but provides information designed to influence the listening party or view it. Hafied Cengara mentions that propaganda is a communication activity that is closely related to persuasion. Propaganda is interpreted as a process of dissemination of information to influence the attitudes and behaviors of one of the community with the motive of ideological indoctrination.

Meanwhile, propaganda was mentioned as a movement or effort to expand influence, attempts to manipulate perception (resurrected emotions of questions suggested when possible between His problems and resolution have nothing to do. Propaganda sometimes conveys the right message, but it is often misleading where generally the content of propaganda only conveys the chosen facts that can produce a certain influence, or rather produce an emotional reaction than a reaction Rational. The goal is to change the cognitive mind of narrative subjects within the target group for specific interests and manipulate the nature of the mind or cognition, as well as directly affecting behaviors in order to provide a response to the desired perpetrator Propaganda. As one communication to many people, propaganda separates the communicators from its community [14].

Communicators in propaganda are actually representatives of organizations that seek to control the community. So that it can be concluded, the communicator in propaganda is an expert in mastery techniques or social control. With a variety of technical, every owner of political interests must use propaganda as a mechanism of social control tools [15].

\subsection{Political Message}

As mentioned earlier that in communication, the most important thing besides communicators is the message. A message is transformed on a point-encoding and password-transfer so that messages are thoughts and ideas in a place on the neural network system from the source or receiver after the encoding occurs in a face to face situation or Through media intermediaries [16].

A message may be, though, but this thought was not physically delivered. However, if the physical form of this message was encoded, it turned into a mind again, that is what caused it to be a message. The affirmation of differences between messages and cues is also expressed by Clevenger and Matthews. It distinguishes messages and cues on the basis of physical forms and their location on the channel. A gesture or signal is a physical event, and the message is only on the channel inside 
the source or receiver. In each communication event, there are three potential messages, i.e., messages sent, received, and that occur within the observer of the communicative situation [17].

Cited by Jennifer more explaining the meaning of thought messages can be ideas, information, opinions, feelings, and others that appear in the communicators ' minds. Feelings can be confidence, certainty, doubts, worries, anger, courage, and others that are coming in the heart and the Communicators mind [18].

In the process of political communication, political messages are the most important component. Referring to the definition of political message in general, the political message is a message brought by political communicators, whether in the form of ideas, thoughts, ideas, feelings, attitudes, or behaviors about politics affecting political communication. Basically, the message content of political communication will consist of [19]:

i. A set of norms governing the transformation of traffic messages.

ii. Guidance and idealistic values that are fixed in the effort to maintain and preserve the ongoing system value.

iii. A number of methods and approaches to realize integrative properties for the occupants of the system.

iv. Characteristics that indicate the identity of the nation. Motivation is a basic encouragement that triggers on efforts to improve the quality of life of the nation.

Sandra Moog looks at political communication messages from a very broad perspective. According to him, the message of political communication can be habits, rules, structures, and environmental factors that affect political life. In fact, the message of political communication was all the political culture that developed in a country [20]. And to smooth the process of delivering the message, it should be a few forms of the intensive massage, there are three types of intensive messages in a political message, namely: power-intensive, influence talks, and authority talks [21].

As for the further explanation, intensive in the content of political messages can be described as follows [22]:

i. Intensive power affects others with threats or promises. The key to power-intensive is that a person has enough ability to support promises and threats, and others think that the owner of that power will do it. So, promises, threats, bribery, and extortion are the means of exchange on power communication based on the ability to manipulate positive or negative sanctions.

ii. The talk of influence without such sanctions above. Influence (due to its prestige or reputation) by successfully manipulated the perception or expectation of another person against the possibility of profit or loss. In communication, the influence of communications exchange is advice, encouragement, demand, and warnings.

iii. Authority talks are giving orders. What was considered a legitimate ruler is the voice of authority and has the right to be influenced. The source of confirmation is equal to the source of authority, namely: religious beliefs, supernatural traits, personal attractiveness, customs, customs, and official position.

\section{Method}

This research is a research library. The author conducted a study from various sources ranging from political party records to the news of the mass media related to the efforts of political actors and political parties to increase women's political participation in Indonesia. All data obtained is then compiled and studied carefully to find the problem discussed.

\section{Results and Discussion}

Women and politics are the discourse that is talked about, even a political to debate. This is due to the fact that when politics are placed in public areas, the Dafinisi, concept, and all the values it contains always puts women outside of the area. Politics has been defined as something negative (bad), political word affiliation is always connected with those in power, men. 
Even when politics are translated into new definitions, as a transparent policy-making activity with the ability of negotiations and participation with a wide base coverage, the distribution of fair and economic resources is Productive, there is a dichotomy between women and politics.

Nearly a decade of discourse on representation and participation of women in politics continues to rise to almost dominating the political agenda, thanks to the gully of the emotion organizations and activists who care about the problem of women voicing The. One of the central issues that then emerged is the implementation of quotas of at least $30 \%$ female involvement in the elections. The discourse continues to evolve and give birth to a controversial debate around gender issues and democracy. The debate arises as a result of three factors that became part of the past of the Indonesian nation. The first factor is the historical (historical) factor, where the nation's history records how low the representation of Indonesian women is in its involvement when the decisionmaking process occurs.

The second factor has to do with continuing political reform, where the transition of democratic life has widened opportunities for women and other community sectors to express their views on formulating and Voice their demands with greater gender awareness and sensitivity in each government and legislative policy.

Then the factor when it comes to the economic crisis of the year 1997 which ignite the demands on the representation of women in each level and all aspects of political life. The economic crisis that struck the lot of influenced women's lives. Due to the crisis's high maternal and infant mortality, the worsening of maternal and child health, the increasing current of female migrant workers (TKW), the increasing numbers of school dropouts and unemployment. Basically, most victims in this crisis are women, so encouraging them to rise up, voicing their needs, and retaining their rights. These adverse impacts raise awareness about the importance of putting together a more gendersensitive political agenda.

The above-mentioned factors have created an atmosphere whereby all community organizations, NGOs, activists, politicians, and international agencies can jointly influence the discourse and direction of government policy concerning Involvement of Indonesian women in political life. Many female NGOs who are engaged in politics now begin to raise political awareness by the people of the Compton. Therefore, now the Indonesian politic institutions have a strong pressure to make the gender issue a central issue in the democratization process, the presence of women in politics is one of the absolute conditions for the realization of the Gender equality.

In short, the need to improve the political representation of women in Indonesia based on an awareness that all the priorities and the political agenda must be revamped, and the reshuffle will be impossible if continuing to use the system The traditional. If women want to look ahead and hold various public strategic positions, then they will be able to build and establish new social and economic values that can accommodate the aspiration needs of women. Improving women's representation means also increasing women's effectiveness in influencing public and political policies taken.

The lack of representation of women in Parliament is caused by a series of obstacles that limit their will and progress. Therefore, various strategies must be simultaneously participated to overcome these obstacles so that the objective of increasing the participation of the legislature in legislative elections can be realized. And those obstacles are gender-sensitive.

As we discussed above that decision-making in the Patriarchate community both in the legislature and other public issues are always taken by men. The dominance of this decision-making resulted in gender inequality on aspects such as education, training, health status, access to resources, and so on. Conceptual gender sensitivity is the ability to understand gender inequality, especially in the division of work and decision making resulting in reduced chance and low women's social status compared to men.

The political field is divided into three factors; The first factor is the support of the political party it belongs to. Legally formal, no political party in Indonesia has included the provisions of the special rights and privileges of women in their organization basics. In the event of the introduction of all political parties always include a very common thing, such as citizenship, age, subject to the rules of the party. In the chapters of decision-making, there are no rules governing the rights and involvement of women. 
Although there is already a political party that includes the interests of women in the formal rules, still its nature is not comprehensive in other parties. In the culture of the community, there are still many practices that do not support the political empowerment of the whole woman; women are placed in an unstrategic position such as treasurer or field that is specialized in women. In an activity, women are often not given the opportunity to develop lobbying and political positions, women's Bisalnya always gets the task of preparing consumption and preparing room equipment, as well as other activities that In no way honing political skills.

Then the second factor is the synergy between women organizations. The absence of a network among women groups interferes with the successful empowerment of women in political participation. The early depoliticization of women's organizations in Indonesia occurred when the new order formed women in containers such as Dhawma women who did not have strong autonomy, so as not to have the strong political bargaining power to give Solution offerings against existing problems, including in the case of women.

Until now, there is still not much organization-organization of women who are truly independent and able to give political advocacy to various problems of women in Indonesia. Therefore, Indonesian women do not yet have proportional political resources to deal with their problems. Then the third factor is the general electoral factor. The automation election system became the most influential factor in this political field, based on data cited by Pippa Norris in his record of "Women's representation and election system", in the Encyclopedia of Elections (ed. Ridharrose) shows the level of The average representation of women is very low in pluralist/majority systems, and higher in proportional systems.

The lack of female political participation is also determined by the internal complainer of the woman, which is low self-esteem. The imaging of women as weak, not independent, and irresponsibility to be absorbed in the subconscious is then felt by women as God's fate. Low selfesteem due to community construction is also a jugum to inhibit women in the process of selfactualization potentiation. As a result is the mindset of women to be very familiar with the participation, until deliberately or has not been utilized by the activity of men.

The next obstacle to advancing as a legislative member in the elections is that women face a major problem when talking about public trust. The concerns and gender injustices manifested in the marginalization and stereotypical forms of women are marginalized in public and political affairs. It becomes a weak creature of life under the rule of men. If you have a political talk, then the shadows that arise are the public world that the contents of men. Women's place is the domestic territory. The quality of women is often seen in the eyes when compared to men. It is at this point that a discrimination against women in the world of democracy.

In a democracy state modem that implements the principle of proportional representation, the presence of political parties can not be removed from the presence of various interests that need to be represented in the community. Only, this function of representation is difficult to implement when the community itself is incapable of involvement in the political process in public space. Therefore, there is a need for a mediator between the community and the government in public spaces so that the interests of the community is not always harmed by the dominant interests that have been mastered the government's political superstructure. In this case, the mediator is expected to serve as an educational medium for the community so that the general public and the stakeholders in it are more empowered to engage in the political process in public spaces. One manifestation of the mediator is a political party as a manifestation of the implementation of political socialization function as stated above.

In practice, political parties used various media in the course of conducting political education. The party can hold internal recruitment to conduct a cadre, hold a meeting, or open a restricted, conduct various social activities, publish information through the media. And so forth. Only, among the media, the media that is often used by political parties to reach the larger constituents are the mass media, both print and electronic. Print media can be newspapers and magazines or tabloids and other newsletters, while electronic media can be radio, television, and in the present day is the Internet. 
Relating to the power of media and its relations with the political system, the media has its own power to influence the political system so that the relationship between them is usually characterized by two things, namely [23]:

a. The form and policy of a country determine the pattern of mass media operations in the country, ranging from ownership, display content, to its supervision. So the dominance of the political system affects the media system, so this condition encourages people to conclude that the mass media system that applies in a country to mirror the political system or regime of the country.

b. Mass Media is often the medium of political communication, especially by the rulers. The journalistic tradition began with the interests of the Kings to disseminate the information of his authority. In the next days, every power is always in contact with the mass media for various political interests. In the political world of the modem, the media has even become a necessity to achieve various interests. Every political force can be used to use mass media to launch political affairs. It is only, not always the mass media determined by the political system or the regime of a country, but rather it depends on the distribution of power occurring in the country. In a country where every social group has the same opportunity for the mass media, the mass media can be a channel of political communication to influence the political system or regime of the country. Furthermore, through its social control function, along with other societal institutions, the mass media could inspire persuasive public participation to contribute to changing the political structure.

Thus, as a social institution that has a persuasive social control function, the media can stir up public participation to participate in changing political structures. Mass Media is one of the forms of social phenomena, and its presence can be understood through three approaches [24]:

a. An ethical approach to the existence of mass media institutions and professional actors. The relevance of the more precise theory used is the normative theory, which relates how media institutions should be instrumental.

b. The social sciences approach to the existence of mass media institutions. The relevance of the theory used to explain this phenomenon is the theory of social sciences.

c. A practical approach to the technical work of professionals in mass media institutions

According that, it can be said that the media function as a representation of the audience's reality has a significant referrer. The media has functioned as a form of meaning because the interpretation of mass media over various events can radically change people's interpretation of reality and their pattern of action. In this context, Hamad explained that while not specifically mentioning the language function in determining the depiction of reality, Lippmann could not argue that the depiction must be done through language, both verbal and Non-verbal. In essence, the media is a vehicle where the language is the most likely to construct reality [25].

Furthermore, it can be said that the mass media not only acts as a translator that formulating, designing, and formatting statements about a fact, but the media itself also performs imagery of the fact of the event, a person, Certain groups, or institutions that have actually brought a new world view to the audience in the realities of actual events or events. The power of media in this imaging is a powerful thing to design a new reality that sometimes tends to overdo [26].

From the tradition of thinking of the Frankurt sect with its critical theory, states that establishing the definition of a situation is a dynamic process through a diverse analysis and defining of the strengths of and media work through support for these definitions. Reality is not understood as a set of facts but rather the outcome of a certain view of reality formation. Construction of reality through the media puts the representation into a major issue in critical research. In a critical tradition, the reality is produced by a representation of the dominant social forces that exist within the community. According to the Hall, this critical paradigm not only changes the view of the natural-perceived reality, but it is also argued that the media is the key to the power struggle, where the dominant group values are diagnosed, is made influential, and determines what audiences want [27].

In the process of forming reality, there are at least two things that play a major role: language and political tagging. First, as the structural circles are understood, language is the marking system. That reality can be marked differences in the same event. According to Hall, this cannot be removed from 
how the dominant discourse forms, makes definitions and forms the boundaries of that understanding. The meaning arises from the social combat process, in which each party or group submits one another's own claims of truth [28].

Here, discourse is understood as the social battle arena, and it is all articulated through language. The language and discourse here are regarded as the social combat arena, and the form of reality defining is articulated through language. Both political tagging is political, where social practice can form, control, and determine. Hall's attention point is the role of media in signaling events or reality in a particular view, then demonstrates how ideology power plays. Ideology in the field where the fight from the group is happening in the community. However, this position also shows that ideology is inherent in social production; the production is ready, and. Cultural system [29].

There are several strategies that can be used and maximized to improve women's political participation in Indonesia, including maximizing the mass media; The role of media is no doubt in social life, no one doubting his significant role in modern nature today. In short, the midst of the media community is not merely a means of entertainment, but also the content and information it has to have a significant role in the social process. Media content is the audience's brain consumption. So what is conveyed by the media will cause social change in the community.

The Media is able to embed a picture in our heads. The idea conveyed by the media is what will eventually underlie the audience's response and attitude toward something. Erroneous information will result in an erroneous representation, and it may be that something wrong is considered the truth. Media is strategically used to serve as a means to capture the participation of the legislative candidates in the election to be willing to make a certain party into its political vehicle, this is not another because the media has a Full power to decide which information should be known or not to be known by the public, and automatically this condition places the media as a new image-forming or an individual or institution (political party) its place Shelter.

In the delivery of messages in the mass media, language is the main element. Language is a fundamental instrument in providing a stimulus, language is a tool of conceptualization and narrative, so the importance of language, there will be no narrative and storyline without it.

Second; The role of new media. New Media is a term for media that emerged later along with the development of the Times and modernization. New Media is a media that utilizes digital bits in its utilization, which at the moment, new media is implemented as an Internet. In the era of information technology as now, there are many media that can be used as a means of political education so that the people of Lsbih are able to engage in the political process. One that stands out is the Internet network, where political parties can provide information on policies, programs, and government activities in general and in the societal in particular, and the public can respond Positive response to the information provided. In politics, the presence of Internet media can erode totalitarianism [30].

It is because the Internet has the following characteristics [31]:

a. Internet ability to penetrate the limit. Digital bits not only transcend physical boundaries, but the use of robust channel displacement and encryption packages makes government surveillance and intervention efforts costly, time-consuming, and difficult.

b. The Internet's ability to bypass physical boundaries decreases the power of the government to control its citizens. This capability is also the main facilitator of Internet characteristics, namely: increasing the ability of citizens dramatically to find, accept, and embed information and ideas through the media, regardless of boundaries.

c. The Internet enhances people's ability to freely guild with ' others who share the same views and interests, without being limited by where they are located and freely spreading information, ideas, and jointly championing the agenda Political or other agenda.

d. The Internet restricts the ability of government to regulate the activities of its citizens, partly due to its nature that penetrates physical obstacles and partly because the Internet is capable of empowering individuals.

e. The Internet makes the organization and power of the government to be doubling in several respects, including boundaries within and between governments and the boundary between government and private sectors. 
f. The speed of development and spread of the Internet is difficult to overcome any government, especially by Governments that hold total centralized control.

g. The Internet has the power to change the way governments run activities, forcing them to renew themselves and become more democratic in the process. It can happen in two ways, namely openness and access. The information presented by the Government online is transparent and accessible to its citizens and does not undergo censorship of government officials, who may not want to expose the information. So, the government that hides something from its citizens has the right to be anxious about the power of the Internet.

h. The Internet empowers individuals and small institutions in a variety of ways. Citizens are empowered when dealing with his reign. Employees are empowered to face employers because it is easy to communicate directly with others outside the organizational structure; the Internet provides a wide range of education possibilities as one of the foundations of democratic formation.

With these facilities, the Internet can essentially serve as an educational medium to improve women's political participation in the legislative elections. The process of the aspirations and interests by political parties in the community can be done by giving voters a lot of information about; Political parties, candidates, policies, records of current governance, political systems, and so on. And new Media (Internet) can basically be ensured in the category of what mass media when it is reviewed from its features, functions, and elements. There are three services in the new media, which is very effective for a communicator to provide a persuasive stimulus for its composition.

Third; The role of non-media communication. The organization is a part of the community; the Organiman refers to a unit of rational activity the activities of a number of people to achieve some general-purpose through the division of work and function through the hierarchy of authority and responsibility. Each organization is in a certain physical state, technology, culture, and social environment in which the organization is to be adjusted. Parson has given attention to the importance of relationships between organizational objectives and the broader community; an organization may expect social support for its activities to reflect Community values in its functions.

Likewise, in a political institution where a physical, anything, can distinguish from other organizations. One of them is a form of an organizational culture where the objectives and vision of the mission that the organization has supported a specific purpose. What else if the organization in question is formed based on specific political objectives, all activities in the Organization must be supported by social activities in the Organization.

Pace and Faules say that there are two approaches to understanding the organization, an objective approach, and a subjective approach. The meaning of "objective" in this context refers to that the view of objects, behaviors, and events exist in the real world and regardless of its observation, while "subjective" suggests that reality itself is a contrite Social, reality as a creative process that allows people to create what is "out there" [32].

According to an objective approach, the organization is something of physical and concrete value and is a structure with definite boundaries, something stable. The term "organization" suggests something tangible, summarizes people, relationships, and goals. The subjective approach of organizations looking at organizations is an activity undertaken by people consisting of actions, interactions, and transactions involving people. Organizations are created and cultivated through contacts who are continuously changing and performed by people between each other and not exist independently of those whose behavior is forming the organization.

So based on an objective approach, the organization means a structure, while according to the subjective view of the organization means a process (organizing behavior). In the implications of an objective view, studying the organization is a whole study, how organizations can adapt to the environment's good ways to develop themselves and live, while approaches Subjective knowledge of the organization gained by looking at the behavior and what that behavior means for those who do so, the structure is acknowledged but stresses it on human behavior in the sense of the insignificance of human actions. Both approaches both subjective and objective not only affect the perspective of organizational communication but also in understanding other aspects related to organizational behavior. 
In this study, the authors say that the prevailing dogmatic organization (which was owned by a certain political institution as a party child) used an objective approach in organizing. In the dogmatic organization, the Sturktir arrangement is highly esteemed in that there is a clear Hiarakis in the organization. The implication is the organization's perspective on the process of delivering the message and the construction of behavior within the organization itself as one-way and should internalize its members [33].

\section{Conclusion}

First, in the selection of media that will be used to attract sympathy and conduct political persuasion to the cadres and political investigators of women-owned, the party can not believe it to the traditional media that exist today Because it will compete with actors and other political parties who have large funds. More with the phenomenon of mass media such as television and newspapers that tend to be capitalistic.

Secondly, the Internet can be an alternative medium to conduct political persuasion by the party as it is a media that can be independently managed and does not need to compete in loading its content with other political actors, besides Its popularity has continued to increase. Even in the last ten years, the Internet has shifted the role of some traditional media such as magazines, radios, films, and outdoor media as information media. Nowadays, internet popularity matches newspapers and television, even in terms of time allocation used in interacting with these media, the Internet occupies the top position, meaning it gets more time allocation than television and Newspapers. Given its media characteristics and various advantages, it is not excessive that the Internet is the most potent interactive media in transforming knowledge, and in influencing attitudes and behaviors. The Internet has the characteristics of friendly and easy to use and is the most economical medium, it's personal, and communication which can also be a massif put this media in a position between the personal media and the mass media.

Thirdly, it is not enough to use only the mass media when the party treats cadres and sympathizers belonging to the parties to participate in the legislative elections. The party must provide special containers as a persuasion medium in the form of organizations. This container will be a medium that can back up against a variety of stimulants done by the party that was previously done with the mass media.

Fourth, the delivered message must be adapted to the media to be used and the background of the communities. Because every investigator and female cadre owned by the political parties in Indonesia has different backgrounds, so if the message content does not match the media and the community background is targeted, then the process Persuasion can not run as expected.

Therefore, there are some things that should be remembered for the increasing participation of women's politics in Indonesia: First, should the political actors in Indonesia who are currently in the environment of policymakers fight for regulation to Mass media such as television and newspapers are free from the interests of any political party, so that content submitted to society is more balanced. If the mass media is able to be freed from certain political interests, then not each party and the public is able to feel its benefits well.

Secondly, using the Internet, it can make political persuasion early on to young people, especially students and students. In that age, young people still have strong idealism to make improvements to a better nation's future. It is therefore not until every persuasive message launched by the political party through the Internet facilities is only pragmatic to meet the quota of at least $30 \%$ representation of women in legislative elections only, but must Have an educative element related to the national problem. Thirdly, the political party must provide the party child organization as a medium that has its own peculiarities in conducting political persuasive of cadres and sympathizers. 


\section{References}

[1] D. Fadillah, "Model Komunikasi 'WOM' Sebagai Strategi Pemasaran Efektif," Humanika, vol. 15, no. $1,2015$.

[2] D. Fadillah and M. N. Farihanto, "Komunikasi Politik antar Koalisi Parlemen di DPR RI," Chanel, vol. 5, no. 1, pp. 111-119, 2017.

[3] W. Sintawati, "Computer mediated communication for construction-supported constructivism in communication and cultural learning,” Int. J. Commun. Soc., vol. 1, no. 1, pp. 34-42, 2019.

[4] D. Fadillah, "Pola Komunikasi Internal Brajamusti Menjelang Pilkada Kotamadya Yogyakarta 2017," Informasi, vol. 47, no. 1, 2017.

[5] D. Fadillah, "STRATEGI KOMUNIKASI PENINGKATAN PARTISIPASI POLITIK KADER PEREMPUAN PARTAI AMANAT NASIONAL KABUPATEN SLEMAN DALAM PEMILU LEGISLATIF 2014," Universitas Gadjah Mada, 2014.

[6] C. Fajri and D. Fadillah, "ANALISA KEGAGALAN KOMUNIKASI POLITIK DALAM PILKADA SERENTAK 2015 DI KABUPATEN SLEMAN (STUDI KASUS PDI PERJUANGAN),” Chanel J. Komun., vol. 5, no. 2, 2017.

[7] D. Rucht, The Strategies and Action Reporteries of New Movements. Cambridge: Polity Press, 1980.

[8] U. Jandevi, "New media for increasing political participation in Indonesia," Int. J. Commun. Soc., vol. 1, no. 1, pp. 1-8, 2019.

[9] Samuel P. Huntington \& Joan Nelson, Partisipasi Politik di Negara Berkembang. Jakarta: PT Rineka Cipta, 1994.

[10] Peter Dahlgren, "The Transformation o f Democracy," in New Media and Politics, Barrie Axford and Richard Huggins, Ed. California: Sage Publication, 2001, p. 64.

[11] J. Deane, "Media, democracy and the public sphere," in Media and Glocal Change: Rethinking Communication for Development, Buenos Aires: Consejo Latinoamericano de Ciencias Sociales, 2005, p. 178.

[12] D. Fadillah, "Strategi komunikasi pembentukan budaya organisasi," Humanika, vol. 14, no. 1, 2014.

[13] D. Fadillah, L. Zhenglin, and D. Hao, "Social Media and General Elections in Malaysia 2018 and Indonesia 2019,” J. Komun. ISKI, vol. 4, no. 1, pp. 1-8, 2019.

[14] M. Ulfah and A. Barry, "Indonesia Leader Forum, post-truth and political interests in social media and television,” Int. J. Commun. Soc., vol. 1, no. 1, pp. 17-25, 2019.

[15] K. Jaya, "Venezuela's communication dynamics in rejection of humanitarian assistance from United States of America," Int. J. Commun. Soc., vol. 1, no. 1, pp. 26-33, 2019.

[16] “Trust Misinformation and Declining Use Social Media News Digital News Repor." [Online]. Available: https://reutersinstitute.politics.ox.ac.uk/risj-review/trust-misinformation-and-declining-usesocial-media-news-digital-news-report-2018. [Accessed: 30-Jun-2018].

[17] E. Murwani, "The Impression Management Strategy of the Candidates of Governor-Vice Governor of DKI Jakarta on Social Media,” vol. 03, no. April 2017, 2018.

[18] jennifer m. brinkerhoff, "Migration, Information Technology, and International Policy," in Diasporas in the New Media Age, an don i a 1 on s o an d pe d r o j. o i a r z a b a l, Ed. Nevada: u n i v e r s i t y of n e v a d a pres s, 2001, p. 39.

[19] Caitlin Chin, "Social Media and Political Campaign," GEORGETOWN PUBLIC POLICY REVIEW, 2019. [Online]. Available: http://www.gpprspring.com/social-media-political-campaigns\#test-copyof-retweets-hashtags-and-political-campaigns.

[20] Sandra Moog and Jeff Sluyter-Beltrao, "The Transformation of Political Communication?," in New Media and Politics, Barrie Axford and Richard Huggins, Ed. California: Sage Publication, 2001, p. 30.

[21] A. Davis, "Democracy and the Internet," The New York Times, 2018. [Online]. Available: https://www.nytimes.com/2018/10/03/opinion/letters/democracy-internet.html. 
[22] Frank Esser and Barbara Pfetsch, Comparing Political Communication: Theories, Cases and Challenge. Cambridge University Press, 2004.

[23] S. Livingstone and P. Lunt, "Talk on Television: Audience participation and public debate," in The mass media, democracy and the public sphere, London: Routledge, 2013, pp. 9-35.

[24] R. E. Hanson, Mass Communication: Living in a Media World (Media and Public Opinion). London: Sage Publication, 2014.

[25] H. Asri, H. Mousannif, and H. Al Moatassime, "Reality mining and predictive analytics for building smart applications,” J. Big Data, vol. 6, no. 66, 2019.

[26] Rashem Rashem, "Public Sphere and the Power of Mass Media," The Circular, 2018. [Online]. Available: http://thecircular.org/public-sphere-and-the-power-of-mass-media/.

[27] D. McQuail, "Mass Communication Theory: An Introduction,” London: Sage Publication, 2009, p. 87.

[28] "Media Sosial dan Fenomena Post Truth." [Online]. Available: http://ksp.go.id/media-sosial-danfenomena-post-truth/index.html.

[29] T. R. O. N. I. T. CULTURE:, C. D. A. P. IN, and C. JOURNALISM, "Television and the public sphere: journalism in a multi-channel environment." [Online]. Available: https://uk.sagepub.com/sites/default/files/upm-binaries/42871_Cushion.pdf.

[30] John Street, "The Transformation of Political Modernity? 210," in New Media and Politics, Barrie Axford and Richard Huggins, Ed. California: Sage Publication, 2001, p. 210.

[31] F. F. Lotan, "Making a positive internet through Socmed Agawe Guyub," Int. J. Commun. Soc., vol. 1, no. 1, pp. 9-16, 2019.

[32] R.Wayne Pace and D. F. Faules, Komunikasi Organisasi. Bandung: Remaja Rosda Karya, 2001.

[33] C. Thousand and C. A. Sage, "Media Organization and Production . Edited," pp. 139-142, 2003. 